\title{
Chronic laxative abuse associated with pancreatic islet cell hyperplasia
}

\author{
M. LESNA, A. N. HAMLYN, C. W. VENABLES, AND C. O. RECORD \\ From the Departments of Pathology and Gastroenterology, Royal Victoria Infirmary, Newcastle upon Tyne
}

SUMMARY Marked pancreatic islet cell hyperplasia was found in a patient with laxative-induced diarrhoea. It is suggested that laxative abuse might be an important aetiological factor in patients with pancreatic islet cell hyperplasia and the watery diarrhoea syndrome but in whom no hormonal excess can be demonstrated.

The abuse of laxatives is a well-recognised cause of watery diarrhoea and is most frequently seen in middle-aged women (Cummings et al., 1974). The diagnosis of this condition can frequently be difficult because such patients ingest laxatives only intermittently and vegetable laxatives cannot easily be detected in stool and urine. The watery diarrhoea syndrome is an important differential diagnosis and, in the absence of a tumour mass, this is frequently associated with pancreatic islet cell hyperplasia (Verner and Morrison, 1974). In this paper we describe a patient with watery diarrhoea caused by chronic laxative abuse in whom marked pancreatic islet cell hyperplasia was also found.

\section{Case history}

A thirty-nine year old Caucasian male first presented in 1971 when he required five admissions to hospital for pilonidal sinus surgery. In 1972 he developed a discharging sinus in the right groin and after excision first developed diarrhoea with the passage of bloodstained mucus. Investigations, including barium meal, barium enema, and sigmoidoscopy, were normal. The diarrhoea continued and after losing $19 \mathrm{~kg}$ ( 3 stones) in weight he was admitted for investigation but no abnormality was found apart from a low serum folate. About this time he first complained of cramping lower abdominal pain. In 1973 he was admitted on three occasions for vasectomy, re-excision of a pilonidal sinus, and appendicectomy (appendix histology normal) but during this time the diarrhoea had subsided. In early 1974 he was admitted with chest pain and later that year he developed heartburn, vomiting, and weight loss of $16 \mathrm{~kg}$ ( $2 \frac{1}{2}$ stones). Investigations were normal

Received for publication 30 May 1977 but a laparotomy and cholecystectomy were performed. Neurological and psychiatric assessments at this time were normal.

In August 1974 he had a lymph node biopsy and soon after this presented to Medical Outpatients with intractable diarrhoea with a stool volume of 3 l per day, some lower abdominal pain, and weight loss. At this time laxative abuse was considered but this he denied and tests for phenolphthalein and magnesium in the stool were negative. The watery diarrhoea syndrome was also considered but serum gastrin, enteroglucagon, secretin, vasoactive intestinal polypeptide, and urinary 5 hydroxyindolactic acid concentrations were normal. He never became hypokalaemic. In May 1975 he was admitted for a further laparotomy because of continuing disabling symptoms but the intra-abdominal organs were completely normal. A distal pancreatectomy was performed and a $10 \mathrm{~cm}$ segment of the ileum was reversed in an attempt to slow down intestinal transit. Postoperatively there was an immediate cessation of symptoms and his weight returned to normal. However, six months later the diarrhoea returned, the bowels being opened 15-20 times per day and he again lost $12.7 \mathrm{~kg}$ ( 2 stones) in weight. Further endocrine assessment revealed normal serum gastrin and secretin, normal plasma and stool prostoglandins, but pancreatic and total glucagon concentrations were slightly raised at $205(0-150)$ and $385(0-250) \mathrm{pg} / \mathrm{ml}$ respectively. The small increases in glucagon were not thought to be of any clinical significance. Phenolphthalein was subsequently recovered from both stool and urine on several occasions. The day after it was suggested to him that a food contaminant might be causing his symptoms the diarrhoea ceased and he became rather constipated. No other self-induced illness has appeared as yet. 


\section{PATHOLOGICAL FINDINGS}

Part of the tail of the pancreas was stained by routine methods after formol saline fixation while the remainder was deep frozen for immunohistochemical studies. Light microscopy revealed very numerous pancreatic islets of variable size, some having formed newly by budding from the ducts. The smallest islets were composed only of a few cells but areas of 'confluent' large islets showing hyperplasia of all endocrine cell types were also present (Fig. 1). A point-counting technique used on multiple sections of pancreatic tissue showed that the area of pancreatic islets in this patient was more than twice that found in two control subjects.

Moderately increased numbers of argyrophilic A cells of the islets were demonstrated by Grimelius silver impregnation technique and prominent hyperplasia of the D cells in the Helleström-Hellman staining method was also seen (Fig. 2).

One of the most striking findings in all sections was the presence of clusters of large poorly-defined areas of eosinophilic cells in the acinar exocrine tissue, rather suggestive of newly forming pancreatic islets (Fig. 3). In the majority of staining methods these cells were still reminiscent of exocrine pancreatic tissue rather than islet cells.
Immunohistochemical studies showed that pancreatic islet cells stained brightly with glucagon, somatostatin, and insulin antibodies but were unreactive to gastrin antibodies.

\section{Discussion}

The term 'nesidioblastosis' was introduced by Laidlaw (1938) to designate diffuse proliferation of islet cells. It has been derived from Greek for 'the cells that differentiate out of the duct epithelium to build islets .... Nesidioblastosis has been associated with the watery diarrhoea syndrome and in 11 out of 54 cases reviewed by Verner and Morrison (1974) the only abnormality demonstrated was diffuse hyperplasia of non-beta pancreatic islet tissue. Eight of these cases were cured by hemipancreatectomy or by complete removal of pancreatic tissue. The pancreatic histology of the patient described in detail by these authors was very similar to that found in the present report, and included increased number of islets, neoformation of islets by budding from the ducts, newly formed small islets, and prominent groups of centroacinar cells. Polak et al. (1975) demonstrated extremely numerous $\mathrm{D}$ cells in the pancreatic islets in cases of severe watery diarrhoea

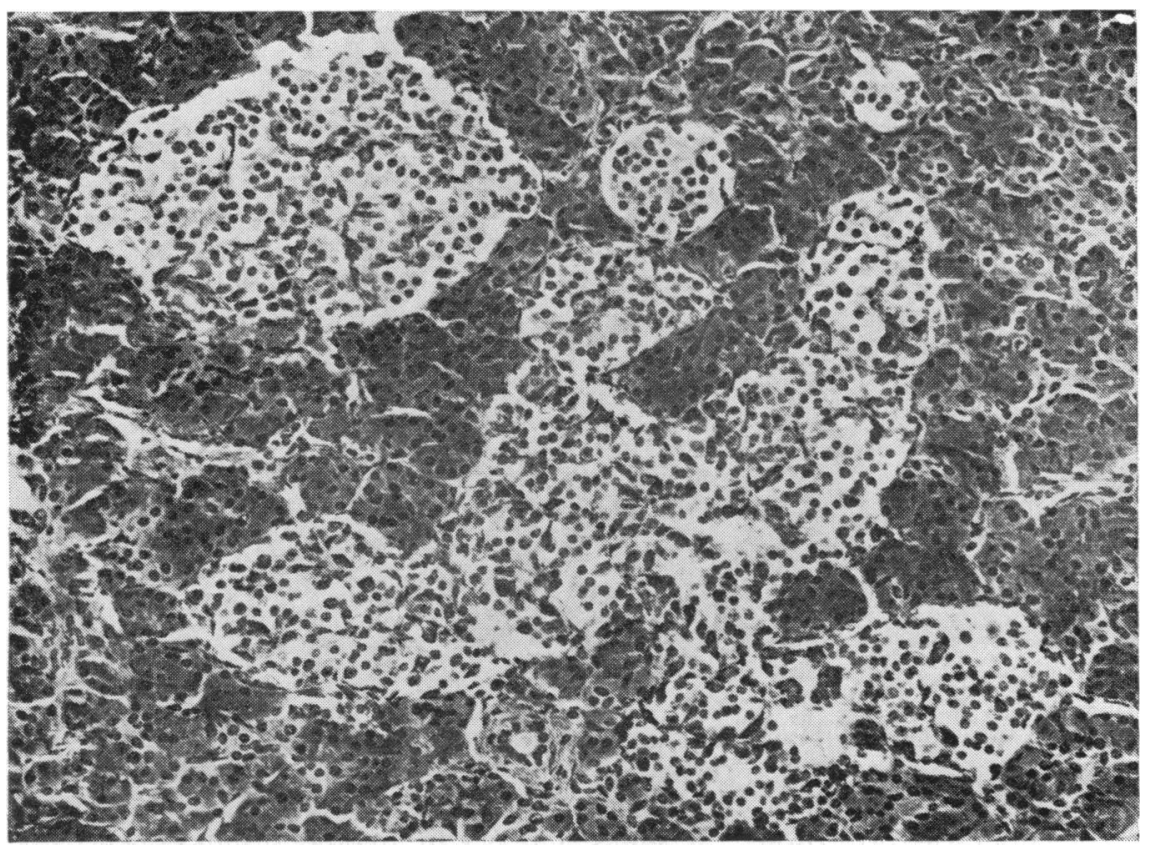

Fig. 1 Hyperplasia of pancreatic islets. Holmes staining. 


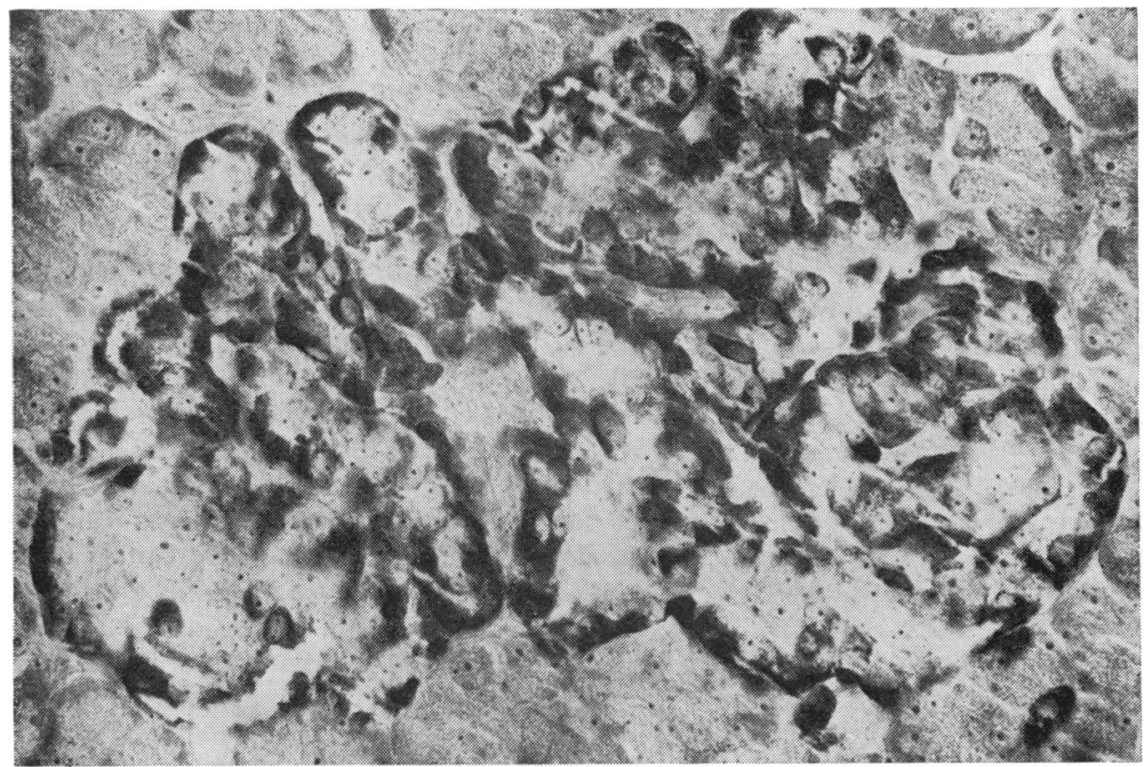

Fig. 2 HelleströmHellman staining of a representative pancreatic islet demonstrating hyperplasia of $D$ cells.

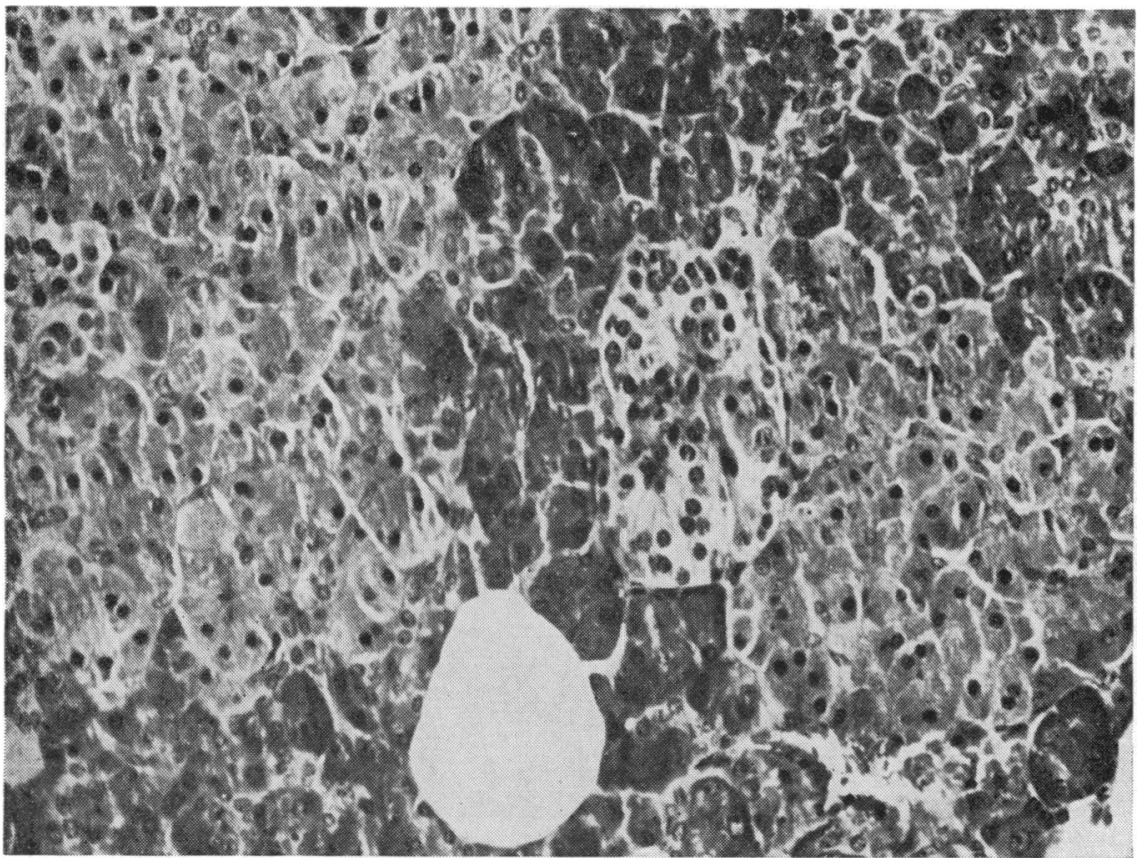

Fig. 3 Acinoinsular transformation in the vicinity and around small pancreatic islets. Haematoxylin and eosin.

unassociated with pancreatic tumour and without increased circulating vasoactive intestinal polypeptide and described secretion of somatostatin by these cells. The term 'pseudo-Verner-Morrison syndrome' was first used by these authors to describe such a condition (Bloom and Polak, 1976). Two cases of 'pancreatic cholera', one of which was attributed to islet cell hyperplasia, were described by Sircus et al. (1970). In other instances pancreatic islet cell hyperplasia has been associated with 
antropyloric gastrinoma (Larsson et al., 1973) and with familial endocrine adenomatosis (Vance $e t$ al., 1969). The problem of acinoinsular differentiation is still the subject of discussion and controversy but has been extensively studied by Sétáló (1970) when light and electron microscopy has shown so-called 'mixed cells' on the border of the pancreatic islets. A mixed cell or cell undergoing transformation should contain simultaneously both the exocrine and endocrine granules, appearances which we have demonstrated in pancreatic tissue of our patient.

It is possible that laxative abuse may have induced hyperplasia and neoformation of islet cells in the patient described, although other alternatives such as laxative abuse and the pseudo-Verner-Morrison syndrome, occurring simultaneously cannot be entirely excluded. It is known that the laxative abuse syndrome is often associated with a variety of abnormal, but misleading, results of various investigations and these often include abnormal pancreatic function, achlorhydria, and spurious hormonal change (Cummings et al., 1974). Many such patients may undergo laparotomy or even resection of the pancreas in pursuit of a mysterious hormonally active gastrointestinal neoplasm before the precise nature of their illness is established.

Laxative abuse is notoriously difficult to diagnose, may cause watery diarrhoea, and should be considered in patients in whom no hormonal excess can be demonstrated.

We thank Dr J. Polak for the immunocytochemical studies and Dr S. Bloom and Dr K. Buchanan for hormonal determinations.

\section{References}

Bloom, S. R., and Polak, J. M. (1976). VIP measurement in distinguishing Verner-Morrison syndrome and pseudoVerner-Morrison syndrome. Clinical Endocrinology, 5, 223s-228s.

Cummings, J. H., Sladen, G. E., James, O. F. W., Sarner, M., and Misiewicz, J. J. (1974). Laxative-induced diarrhoea: a continuing clinical problem. British Medical Journal, 1, 537-541.

Jacobs, W. H., Halperin, P., and Mantz, F. A. (1972). Watery diarrhea and hypokalemia due to nonbeta-islet cell hyperplasia of the pancreas. American Journal of Gastroenterology, 57, 333-340.

Kraft, A. R., Tompkins, R. K., and Zollinger, R. M. (1970). Recognition and management of the diarrheal syndrome caused by nonteta islet cell tumors of the pancreas. American Journal of Surgery, 119, 163-170.

Laidlaw, G. F. (1938). Nesidioblastoma: the islet tumour of the pancreas. American Journal of Pathology, 14, 125-134.

Larsson, L. I., Ljungberg, O., Sundler, F., Håkanson, R., Svensson, S. O., Rehfeld, J., Stadil, F., and Holst, J. (1973). Antro-pyloric gastrinoma associated with pancreatic nesidioblastosis and proliferation of islets. Virchows Archives Abteilung A. Pathologische Anatomie, 360, 305-314.

Polak, J. M., Bloom, S. R., Arimura, A., and Pearse, A. G. E. (1975). Pancreatic D cells in normal and pathological human pancreas. Gut, 16, 837 (Abstract.)

Sétáló, G. (1970). Light microscopic demenstration of acino-insular transformation. Acta Morphologica Academia Scientiarum Hungaricae, 18, 359-367.

Sircus, W., Brunt, P. W., Walker, R. J., Small, W. P., Falconer, C. W. A., and Thomson, C. G. (1970). Two cases of 'pancreatic cholera' with features of peptide-secreting adenomatosis of the pancreas. Gut, 11, 197-205.

Vance, J. E., Stoll, R. W., Kitabchi, A. E., Williams R. H., and Wood, F. C., Jr. (1969). Nesidioblastosis in familial endocrine adenomatosis. Journal of the American Medical Association, 207, 1679-1682.

Verner, J. V., and Morrison, A. B. (1974). Endocrine pancreatic islet disease with diarrhea: report of a case due to diffuse hyperplasia of nonbeta islet tissue with a review of 54 additional cases. Archives of Internal Medicine, 133, 492-500. 